\title{
Study on Location Plan of Temporary Shelter for Tsunami Disaster in Kuta Bay of Central Lombok
}

\author{
Adi Mawardin \\ Research Center and Development of Water Resources, Ministry of Public Works and Housings, Central Jakarta, INDONESIA \\ Adimawardin14@gmail.com
}

\begin{abstract}
Historical record showed in 1977, tsunami attacked Lombok and caused extensive damages due to tectonic activity. Kuta Bay located in the southern area of Lombok has a high risk of earthquake and tsunami, thus mitigation plan on tsunami attack is very important. This study aimed to determine the arrival time, run-up height of tsunami and the coverage areas, so it could be used to determine the temporary shelter location (Tempat Evakuasi Sementara-TES). Simulation of the tsunami wave propagation used the TUNAMI modified (beta version) program with three scenarios of earthquake magnitude variation (Mw), namely 7.7, 8.1, 8.3, and 7.9 (based on the Sumba earthquake event in 1977). Field surveys, questionnaire distributions, and interviews were used in determining input parameters of Tsunami Evacuation Simulation (Simulasi Evakuasi Tsunami-SET) by using 2011 EVACUWARE 1.0 version. Tsunami wave propagation simulation showed the tsunami arrival time on Kuta Bay ranged between 21 - 38 minutes. Tsunami run-up height was about 1.01 - 8.71 meters along Kuta Bay, with the farthest distance of inundation was 860 meters from the seashore. The percentage of survivors based on SET results in scenario 1 and 2 for 20 minutes of evacuation time were respectively, $63.62 \%$ and $93.27 \%$.
\end{abstract}

Keywords: Kuta Bay, Tsunami, Temporary Shelter Location

\section{BACKGROUND}

The territory of Indonesia is a disaster-prone area, particularly for earthquake and tsunami. This is because Indonesia is located on the meeting point of three tectonic plates, which are the Eurasian Plate, Indo-Australian Plate, and Pacific Ocean Plate. The tsunami-prone areas are located on the west coast of Sumatera, south coast of Java, Bali, and Nusa Tenggara, as well as the northern coast of SulawesiMaluku and northern coast of Papua.

The Kuta Bay area is located on the Pujut Sub-district of Central Lombok Regency. This bay features three kilometers of white sandy beach that function as tourism spot in Lombok Island. Visitors are abundant in both workdays and time of holidays. The facilities in the tourism spot are hotel, shopping area, and travel offices. This area is also becoming the destination for windsurfing, kayaking, deep sea fishing, and paragliding.

Behind all these potencies, Kuta Beach has high vulnerability to earthquake disaster. The geographical location of Kuta Beach directly faces the subduction zone in the Lombok southern waters. Historical record shows the tsunami that caused major damage was occurred due to tectonic activity in the southern area of Lombok in 1977.

Disaster mitigation effort in Kuta Bay is very required in which the Kuta Bay is a southern coastal area that is closely located with the source of earthquake and tsunami. The mitigation could be realized by constructing a temporary shelter in Kuta Bay that could be quickly reached by the people at time of tsunami event (Law 24/2007, Law 27/2007; District Regulation of Central Lombok Number 46/2014). In general, the location of the Temporary Shelter could be in the shape of natural highland area, plateau, and new structure that is designed to withstand earthquake and tsunami ( Federal Emergency Management Agency, 2008).

\section{HAZARD POTENCY OF EARTHQUAKE AND TSUNAMI IN WEST NUSA TENGGARA}

The tectonic order of West Nusa Tenggara is influenced by fore-arc thrust system of the subduction zone from the southern part of Nusa Tenggara and back arc thrust on the northern part of Nusa Tenggara (starts from north Bali Island until Flores Island) (Figure 1). This then made West Nusa Tenggara have quite high vulnerability potency to earthquake (Sudiartha \& Santoso, 2011). 


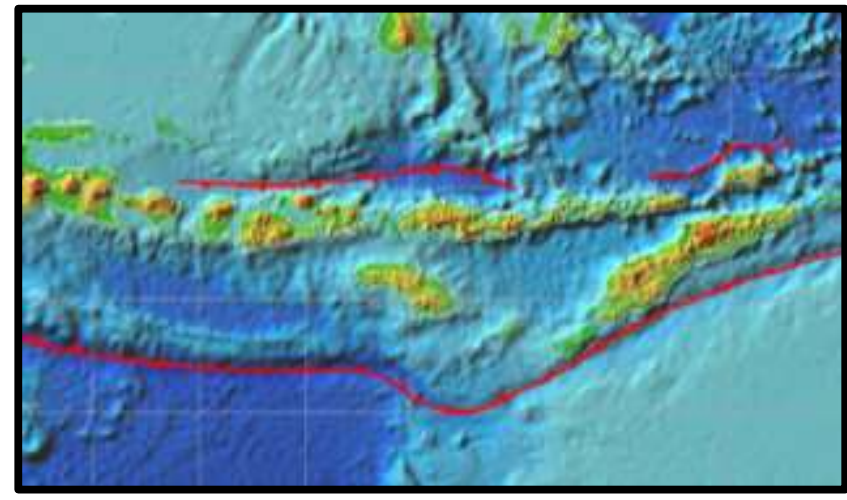

Figure 1. Source of back-arc thrust earthquake and subduction zone

Shallow earthquakes on the northern part of the island's arc were caused by the Bali back arc thrust activity which is a reverse fault geological structure that extends until Flores Sea. Shallow earthquakes that are generated by the back arc thrust of the islands are fewer when compared with shallow earthquakes caused by subduction zone activity because the subduction zone has a much wider area. However, the back-arc thrust activity is more dangerous because of its shallow characteristic, which is less than $40 \mathrm{~km}$.

Earthquake is a natural event whose timing still hard to be predicate. The data on earthquake center distribution shows that the earthquake centers are located in the southern and northern area of West Nusa Tenggara, which is the Indian Ocean and Flores Sea. The depth of the centers ranges on $0-70 \mathrm{~km}$ which is included in shallow to moderate earthquake.

Based on the historical record, tsunami disaster in the Java subduction zone that was occurred in 1970-2016 in the coordinate limit described in Figure 2, with strength greater than $\mathrm{Mw}=6.0$ and hypocenter of $<70$ $\mathrm{km}$, were about 34 earthquake events (USGS data).

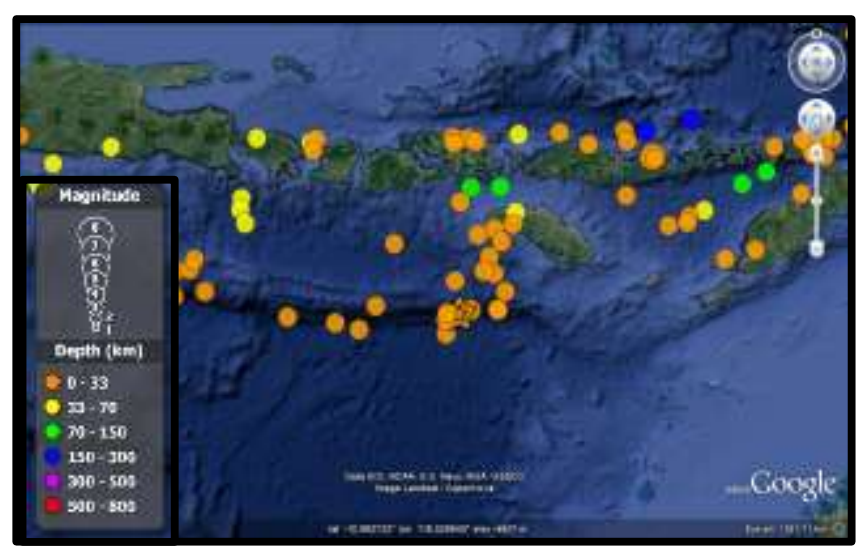

Figure 2. Distribution of earthquake (point) and tsunami (star) in West Nusa Tenggara
If observing the earthquake centers that are commonly located in the Indian Ocean with center depth of 0-70 $\mathrm{km}$ (shallow to moderate earthquake), and a frequent enough large earthquake events, then there is a possibility that the southern and northern coast of West Nusa Tenggara being hit by tsunami.

On August $19^{\text {th }}, 1977$ at 06.08 AM local time, earthquake had occurred with magnitude strength of $\mathrm{Mw}=7.9$ on the southern part of Sumba Island, precisely on epicenter of $11.085^{\circ} \mathrm{S}$ and $118.464^{\circ} \mathrm{E}$ (USGS). Because the earthquake center was close with Sumba Island, it is also commonly known as Sumba Earthquake, which then had triggered tsunami waves in southern part of Bali Island, Lombok, Sumbawa, and Sumba of the Nusa Tenggara Islands.

After the tsunami event, field survey was conducted by International Tsunami Information Center (ITIC) of Hawaii and Geophysical and Meteorological Agency from Jakarta, which started from August $25^{\text {th }}$ until September $7^{\text {th }}, 1977$; as reported by Nakamura (1979). The calculated casualties were 107 deaths, 54 people were missing, 1,125 people were injured, and all were from Lombok Island and Sumbawa. The total losses from both islands reached number Rp. 239, 474,000 .

\section{TSUNAMI MODELING}

The simulation used three magnitude scenarios, which are $\mathrm{Mw}=7.7 ; \mathrm{Mw}=8.1$; and $\mathrm{Mw}=8.3$; that was centered perpendicular to Kuta Bay and located in the subduction zone. One of the simulations was based from 1977 tsunami event with $\mathrm{Mw}=7.9$. Scenario of earthquake center is shown in Figure 3.

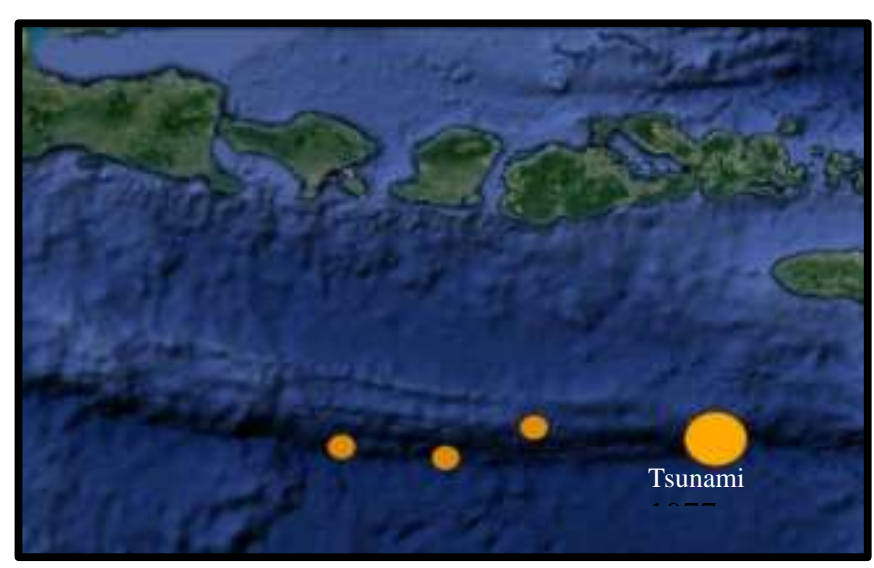

Figure 3. Scenario of earthquake center and modeling layer

Input parameters needed for the tsunami source modeling are location of earthquake epicenter, earthquake magnitude, strike, dip, slip, length and width of the fault (Kongko, 2011). The calculation of 
the length, width, and dislocation of the thrust in this research used the Wells \& Coppersmith equation (1994).

$M w=4.38+1.49 \log (R L D)$

$M w=4.06+2.25 \log (W I D)$

$M w=4.07+0.98 \log (R A)$

In which $R L D$ is subsurface rupture length $(\mathrm{km}), W I D$ is subsurface rupture width $(\mathrm{km})$, and $R A$ is subsurface rupture area $\left(\mathrm{km}^{2}\right)$.

\section{RESEARCH METHOD}

\subsection{TUNAMI Program}

The tsunami modeling simulation used the TUNAMI modified (beta version) that was currently in the development stage by Benazir (2016), whereas the source code on the main program of TUNAMI N-2 which used FORTRAN 77 programming language was converted into basic language with Visual Basic.NET for modeling utilization efficiency both in simulation preparation and better interface. Related supporting data are as follows:

a) Topography data from topographical map scale 1:25.000 from Geospatial Information Agency (Badan Informasi Geospasial, formerly known as Badan Koordinasi Survei dan Pemetaan Nasional-Bakosurtanal)

b) Bathymetry data from website (Scripps Institution of Oceanography, 2017).

c) Information data on earthquake center on around the south coast of Lombok Island, from website (USGS, 2017).

d) Data on roughness value (Manning), with assumption that the surface channel is in good condition with no obstruction, therefore the given $\mathrm{n}$ value is 0.025 which then according to bathymetry and topography data was saved into text format (*.txt).

e) Data on measurement point based on Cartesian coordinate digitation. Coordinate value and measurement point were located on around the Kuta Beach.

\subsection{Field Survey and Interview}

Research location survey was the initial step in determining the location point that has great potential for tsunami disaster. Kuta Village has directly faced the Indian Ocean; therefore, it has great potency to tsunami disaster.

Questionnaire interview with locals and visitors of Kuta Beach was related with the people's preparedness in dealing with tsunami disaster. The result of this interview then would become the researcher's reference for process of tsunami evacuation simulation data input.

\subsection{Tsunami Evacuation Simulation}

Implementation of tsunami evacuation simulation with Evacuware version 1.0 program needed supporting data that are related with the environment that surrounds the research location, as well as agent data (locals) that describes the characteristic of the community. Obtained data are as follow:

a) Location plan of the temporary shelter were on Kuta Village Hall and Mandalika Art Market, based on the existing installed sign of temporary shelter location.

b) The condition of road infrastructure and temporary shelter plan were based on field observation result.

c) Total population data from Central Bureau of Statistic of Central Lombok Regency.

d) Delay time data for tsunami evacuation simulation was obtained from result of interview with locals in Kuta Village.

\section{RESULT}

\subsection{Result of TUNAMI Program Simulation}

a) Scenario 1

In this scenario, it was assumed that earthquake with strength of $\mathrm{Mw}=7.7$ (dislocation dimension 111x50) occurred in position of $11.143 \mathrm{~S} ; 115.418 \mathrm{E}$, and on depth of $10 \mathrm{~km}$, with distance of $268 \mathrm{~km}$ from south of Kuta Beach, Lombok. Scenario 1 tsunami propagation from the source location until arrival in Kuta Bay is shown in Figure 4.

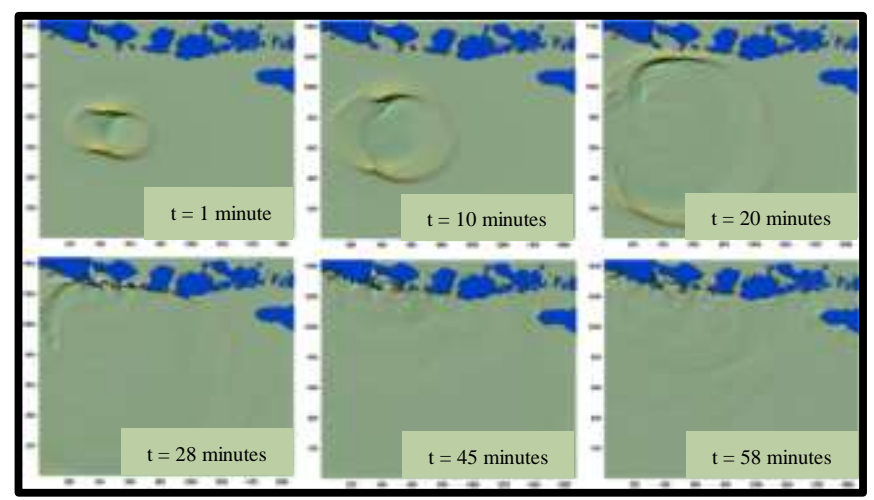

Figure 4. Scenario 1 tsunami wave propagation

b) Scenario 2 
In this scenario, it was assumed that earthquake with strength of $\mathrm{Mw}=8.1$ (dislocation dimension 165x70) occurred in position of $11.249 \mathrm{~S} ; 116.267 \mathrm{E}$, and on depth of $10 \mathrm{~km}$, with distance of $262 \mathrm{~km}$ from south of Kuta Beach, Lombok. Scenario 2 tsunami propagation from the source location until arrival in Kuta Bay is shown in Figure 5.

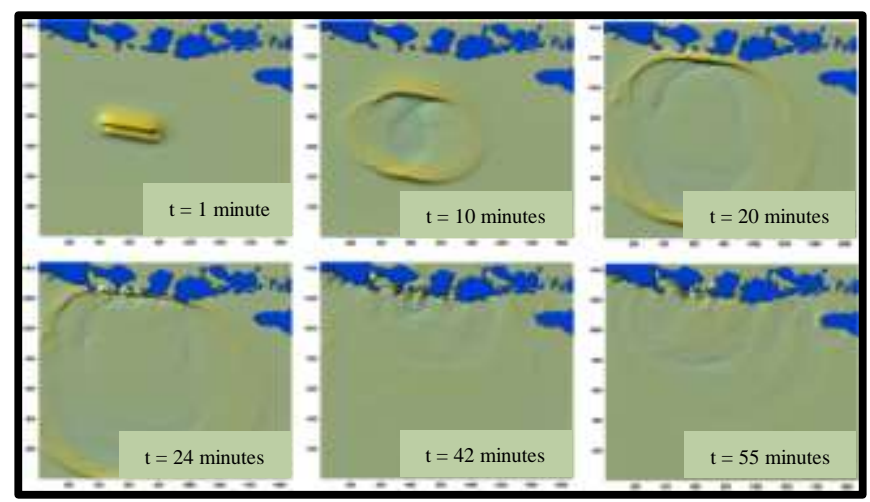

Figure 5. Scenario 2 tsunami wave propagation

\section{c) Scenario 3}

In this scenario, it was assumed that earthquake with strength of $\mathrm{Mw}=8.3$ (dislocation dimension 246x75) occurred in position of $246 \times 75 \mathrm{~S} ; 116.987 \mathrm{E}$, and on depth of $10 \mathrm{~km}$, with distance of $242 \mathrm{~km}$ from south of Kuta Beach, Lombok. Scenario 3 tsunami propagation from the source location until arrival in Kuta Bay is shown in Figure 6.

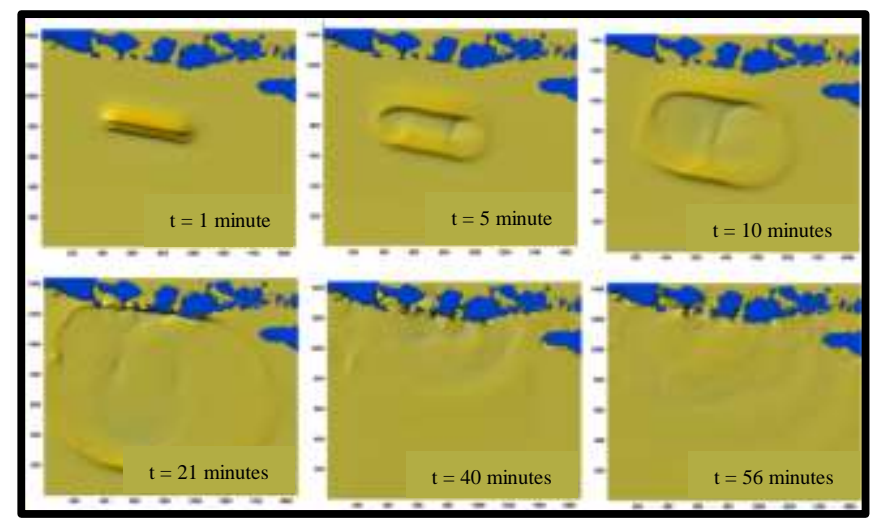

Figure 6. Scenario 3 tsunami wave propagation

\section{d) 1977 tsunami event}

Earthquake event that triggered tsunami in the waters of West Nusa Tenggara south coast occurred on August $19^{\text {th }}, 1977$. According to USGS, earthquake with strength of $7.9 \mathrm{Mw}$ (dislocation dimension of 150x75) was located in position of $10.085 \mathrm{~S} ; 118.464$
E, with depth of $33 \mathrm{~km}$ and distance of $342 \mathrm{~km}$ from south of Kuta Beach, Lombok. Tsunami propagation based on 1977 tsunami event from the source location until arrival in Kuta Bay is shown in Figure 7.

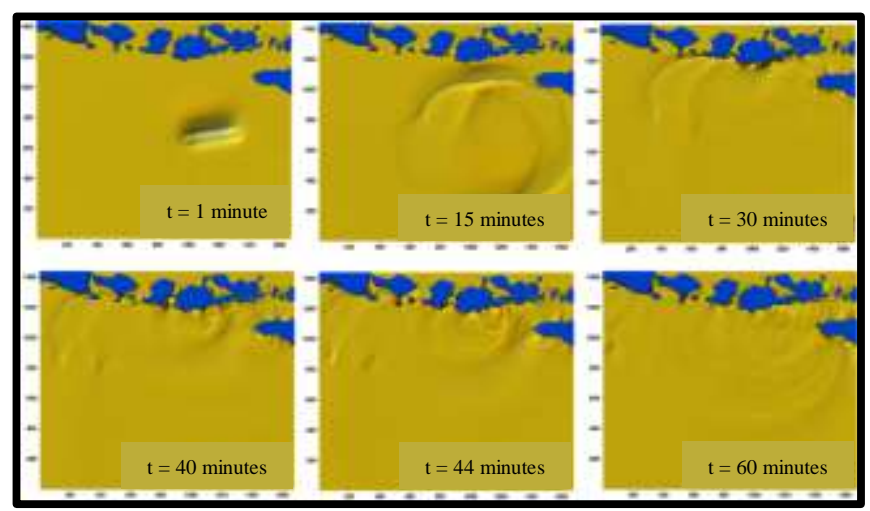

Figure 7. Tsunami wave propagation (1977 tsunami event)

The result was obtained from conducted simulations, both on the magnitude scenario alternatives and on 1977 tsunami event. Table 1 gave results on arrival time, run up height, and inundation distance on the measurement location on along the Kuta Beach. The coverage distance is also shown in Figure 8. Run up elevation (maximum) and highest inundation height (maximum) that was caused by magnitude 8.3 scenario with dislocation dimension $246 \times 75$ on distance of $242 \mathrm{~km}$ from south of Kuta Beach, Lombok. Longest inundation duration and the fastest arrival time of tsunami wave to reach the land were also occurred in magnitude 8.3 scenario, which is about 21 minutes. Therefore, magnitude 8.3 scenario is the most dangerous and should be aware.

Table 1. Arrival time, run up and inundation on measurement location number 2

\begin{tabular}{lllll}
\hline & \multicolumn{3}{c}{ Magnitude Scenario } & \multicolumn{1}{c}{$\begin{array}{l}\text { Tsunami } \\
1977 \\
(\mathrm{Mw}=7.9)\end{array}$} \\
\cline { 2 - 4 } Observation & $\begin{array}{l}1 \\
(\mathrm{Mw}=7.7)\end{array}$ & $\begin{array}{l}2 \\
(\mathrm{Mw}=8.1)\end{array}$ & $\begin{array}{l}3 \\
(\mathrm{Mw}=8.3)\end{array}$ \\
\hline $\begin{array}{l}\text { Max. Run Up } \\
\begin{array}{l}\text { Elevation } \\
(\mathrm{m})\end{array}\end{array}$ & 3.01 & 7.11 & 10.71 & 5.40 \\
$\begin{array}{l}\text { Inundation } \\
\text { duration } \\
\text { (minute) }\end{array}$ & 16 & 19 & 31 & 6 \\
$\begin{array}{l}\text { Height } \\
\text { (maximum) }\end{array}$ & 1.01 & 5.11 & 8.71 & 3.40 \\
$\begin{array}{l}\text { Inundation } \\
\text { (m) }\end{array}$ & & & & \\
$\begin{array}{l}\text { Time of wave } \\
\text { reach the land } \\
\text { (minute of) }\end{array}$ & 26 & 29 & 21 & 38 \\
\hline
\end{tabular}




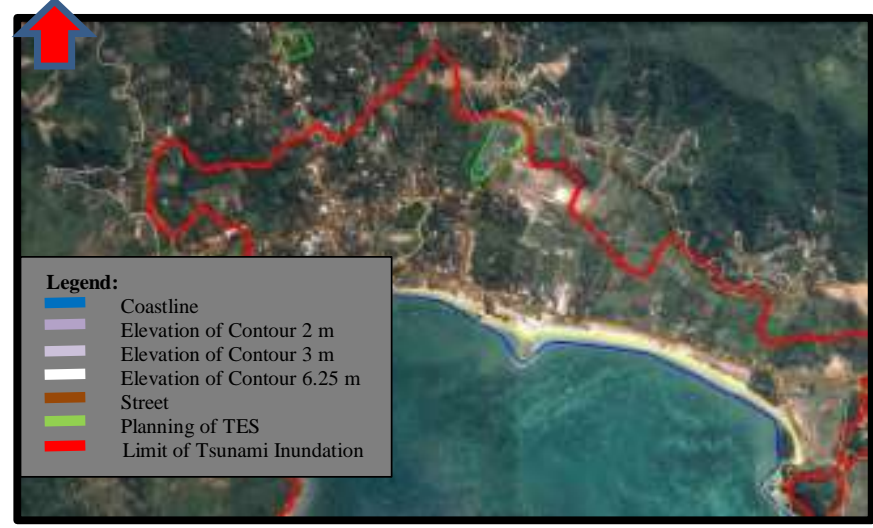

Figure 8. Tsunami coverage area

\subsection{Tsunami Evacuation Analysis}

Kuta Village is located on the south coast of Lombok Island, with most of the resident's work as fishermen. In year 2016, the village population was 8,216 people, as shown in Table 2 (BPS Kabupaten Lombok Tengah, 2016).

Table 2. Population of Kuta Village (BPS Kabupaten Lombok Tengah, 2016)

\begin{tabular}{llll}
\hline Age & Male & Female & Total \\
\hline $0-4$ & 480 & 429 & 909 \\
$4-10$ & 433 & 388 & 821 \\
$10-20$ & 843 & 749 & 1592 \\
$20-35$ & 878 & 985 & 1863 \\
$35-50$ & 814 & 863 & 1677 \\
$50-70$ & 604 & 656 & 1260 \\
$70>$ & 42 & 52 & 94 \\
Total & 4.094 & 4.122 & 8.216 \\
\hline
\end{tabular}

Evacuation route in the Kuta Village uses the road in Pujut Sub-district. On average, the roads are residential streets with asphalt material.

The width of the road used for evacuation route affects the movement of the people when evacuating; therefore, wider road would make the people easier to move when evacuating. As for the Kuta Village, based on observation result and direct measurement on field, the temporary width of the road used to reach evacuation location was 6-8 meters. Following is the list on road condition in Kuta Village:

a) Pariwisata Street (Figure 9) is main local road located in Kuta Village that is used as access opener for residential area with Rembitan Village. Pariwisata Street consists of 2 lanes and 2 carriageways, \pm 8 meters wide, with asphalt pavement.

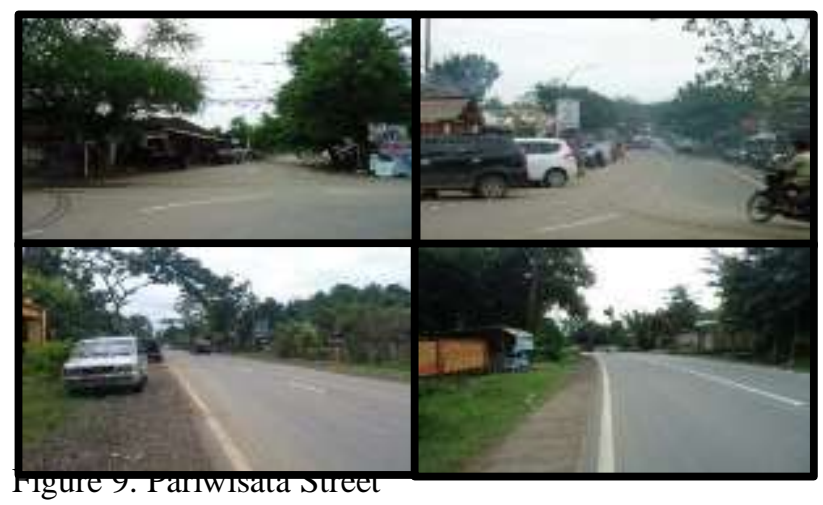

b) Pantai Kuta Street (Figure 10) is a local road that extends from the west to the east of Kuta Beach until Tanjung A'an Beach of Sukadana Village and Gerupuk Beach. Pantai Kuta Street consists of 2 lanes and 2 carriageways, \pm 8 meters wide, with asphalt pavement.

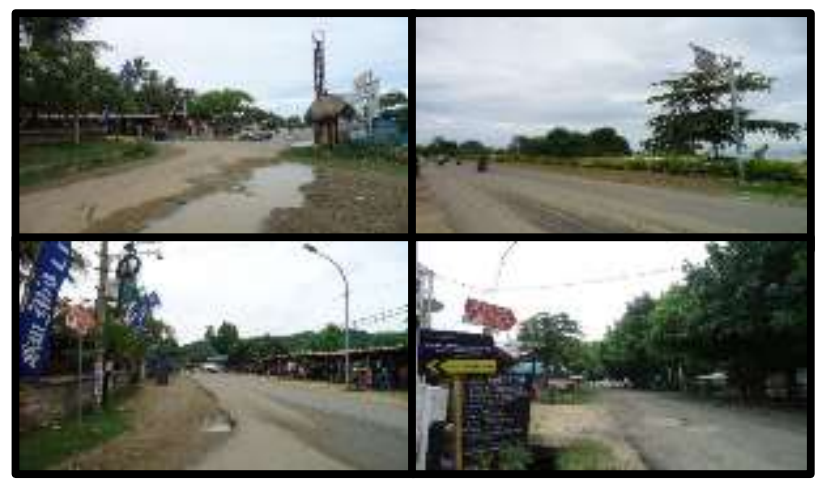

Figure 10. Pantai Kuta Street

c) Kuta-Prabu Street (Figure 11) is a local road that connects road access from Kuta Village to Prabu Village. Kuta-Prabu Street consists of 2 lanes and 2 carriageways, \pm 6 meters wide, with asphalt pavement. The friction value on roads in Kuta Village is shown in Figure 12.

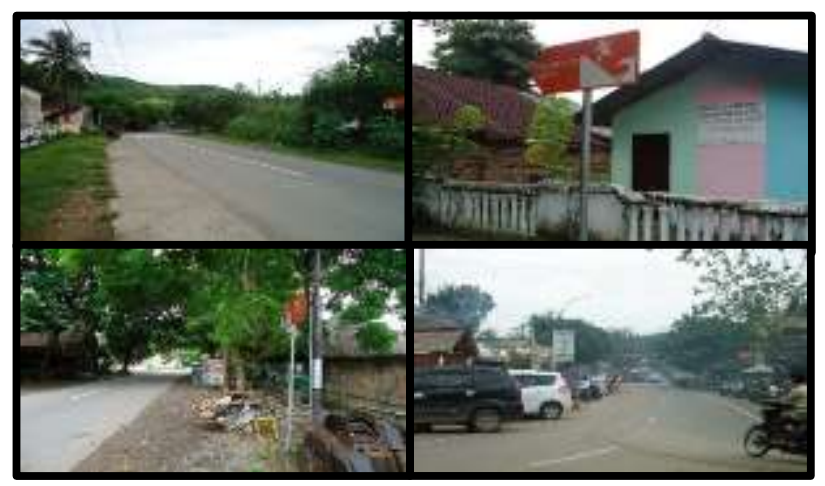

Figure 11. Kuta-Prabu Street 


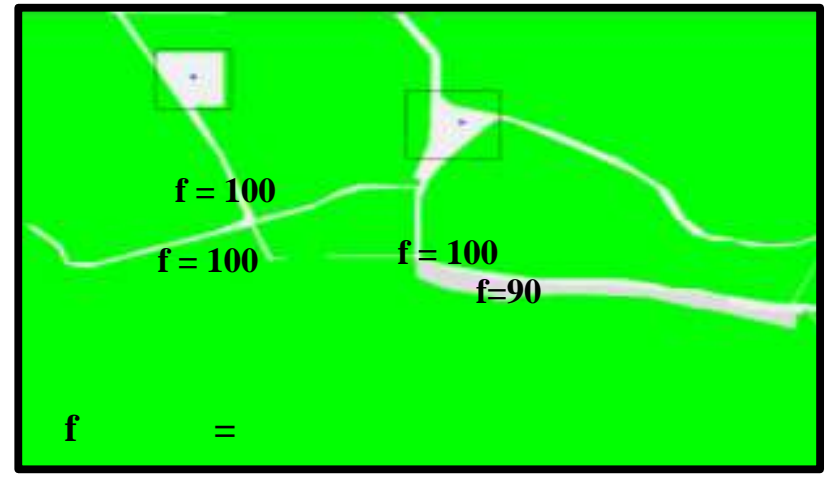

Figure 12. Friction value of streets on Kuta Village

Topography condition in Kuta Village is relatively flat, therefore the Regional Board for Disaster Management (BPBD-Badan Penanggulangan Bencana Daerah) needed to establish a vertical evacuation building. Until the time of this research, 3 assembling points and 1 temporary shelter have been set.

Based on the field observation analysis, the location of assembling point was on the north-east of Kuta Village, started from Kuta Village Jami' Mosque until Kuta Village Hall, while the temporary shelter that on Kuta Village Mandalika Art Market was located on the eastern side (see Figure 13)

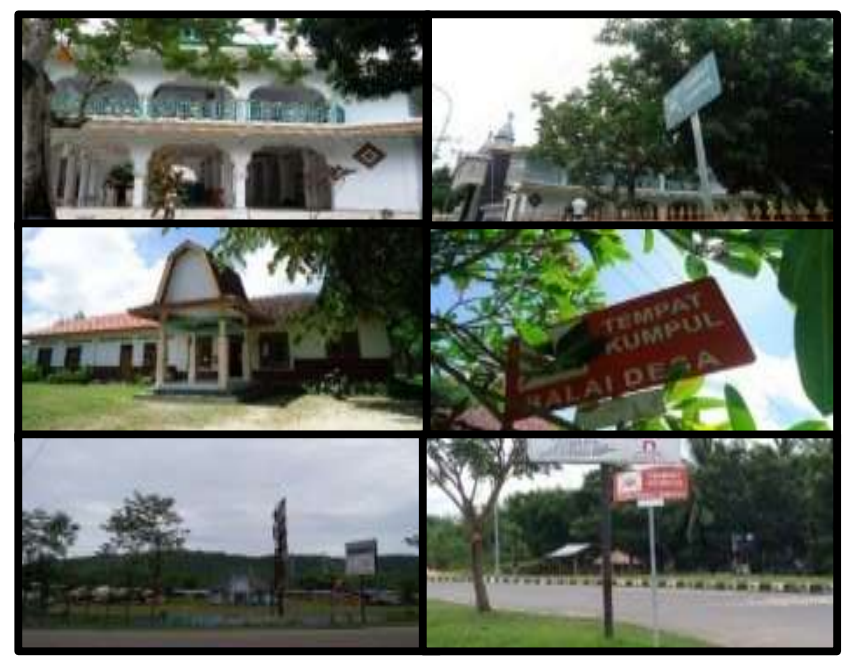

Figure 13. Evacuation location in Kuta Village

\subsection{Preparedness of Residents and Visitors of Kuta Beach}

Assessment of preparedness in evacuation was conducted through survey on locals and visitors of Kuta Village on within $\pm 1 \mathrm{~km}$ of Mandalika Art Market as one of the temporary shelters in Kuta Village. Based on the analysis on knowledge of location and route to temporary shelter, it could be concluded that in general, residents in within $1 \mathrm{~km}$ of the temporary shelter have participated in tsunami socialization; therefore, they know the tsunami-hazard area, and where to run to save themselves at time of tsunami event.

The same issue was also expressed by the visitors of Kuta Beach. In general, they already knew that Kuta Beach is a disaster-prone area. However, a lot of respondents still do not know the nearest temporary shelter and the route to the existing temporary shelter.

Regarding the manner and believe of the residents to save themselves when they got information about upcoming tsunami, most of Kuta residents and visitors of Kuta Beach are sure that they could save themselves. This was proven by several things, as follows:

a) Most of them chose to directly run at time of earthquake, despite no tsunami information has been issued; this showed that those who live in coastal area are more independent in the case of tsunami preparedness.

b) When they already certain to evacuate, most Kuta Village residents would choose to search for their family members. Unlike the visitors of Kuta Beach that choose to prepare their documents and valuables before heading to the evacuation site.

c) Kuta residents are certain that they able to run away in time $\leq 5$ minutes before tsunami arrive. Unlike the Kuta Beach visitors that are certain that they able to run $\leq 1$ minute to save themselves when tsunami warning is heard.

d) They would choose evacuation location in the form of highland/hill that is located around the Kuta Village.

e) Both the residents and Kuta Beach visitors are mostly preferred to get to evacuation site by motorcycle, in which this could disrupt the evacuation route and would cause traffic congestion on along the route.

\subsection{Analysis on Tsunami Arrival Time}

The most important issue when preparing an evacuation scenario, based on the possibilities at tsunami event, is the time available to evacuate. Parameters that very influential to evacuation time are the location of the earthquake source that would generate tsunami, and early warning system for tsunami hazard. The further the location of earthquake source, the more time needed for evacuation; and the shorter time needed for early warning system, the more time left for tsunami evacuation. Based on the questionnaire interview result, the delay time of each resident for evacuation are different. 
Table 3. Each resident's delay time for evacuation

\begin{tabular}{lll}
\hline $\begin{array}{l}\text { Time } \\
\text { (minute) }\end{array}$ & $\begin{array}{l}\text { Percentage of } \\
\text { Residents } \\
(\%)\end{array}$ & Total (people) \\
\hline 1 & 28 & 2,300 \\
5 & 31 & 2,541 \\
10 & 6 & 493 \\
15 & 12 & 986 \\
20 & 23 & 1,890 \\
\hline
\end{tabular}

The Table 3 shows that Kuta Village residents that would be ready to evacuate at $1^{\text {st }}$ minute are $28 \%$; on $5^{\text {th }}$ minute are $31 \%$; on $10^{\text {th }}$ minute are $6 \%$; on $15^{\text {th }}$ minute are $12 \%$, and on $20^{\text {th }}$ minute are $23 \%$.

Based on the conducted tsunami simulation, the fastest arrival time of tsunami wave to land on magnitude 8.3 scenario was 21 minutes. The residents should be ready shortly after earthquake occurred, even though tsunami warning has not been issued. This is to avoid population accumulation at time of evacuation process.

At time of tsunami evacuation, it is highly recommended for residents to evacuate by walking or running. This is chosen to avoid traffic accidents and congestion from motorized vehicles.

\subsection{Simulation Result of Evacuware Program}

There were parameters in Evacuware Version 1.0 that have been determined for the evacuation implementation, namely speed and human strength, which was randomly given based on the parameter value. To determine the right average for human running speed, evacuation simulation for human running speed has been conducted in Paratringtis (Triatmadja, 2015).

In this evacuation simulation, it was conditioned that the locals, without any additional outsider, coming closer to the beach. It was also conditioned that there are two temporary shelters, the Kuta Village Hall and Kuta Village Mandalika Art Market.

On the Evacuware Version 1.0 program, the evacuation direction was not specified, therefore the residents freely moved to anywhere they want. The determination for delay time of every resident was obtained from result of questionnaire interview on Kuta Village residents. The observation was conducted for 20 minutes based on the tsunami evacuation simulation.

\subsection{Analysis of Vertical Evacuation Building}

From the aspect on the adequacy of available space, the two locations of the existing temporary shelters is actually could already be used for a safe tsunami evacuation site. From the observation result, the accesses to evacuation location are already used asphalt material, yet it is still relatively narrow to Kuta Village Hall and Kuta Village Mandalika Art Market. This could be seen from simulation 1, whereas in time period of $\leq 20$ minutes, there were only $63.62 \%$ of residents that could reach both of the location sites. The factors that affect the number of survivors is evacuation route condition and density level, population's condition, width of the lane, good road condition, and the slope of evacuation road that would influence the people's moving space at time of evacuation. Other than those factors, the different evacuation delay time of each resident greatly affects the number of survivors; this then would need the preparedness of the locals on around the Kuta Beach at time of earthquake event. Residents that live near the beach should aware that when earthquake occurs they should immediately run to highland or existing evacuation site, this is because they live in beach area that is prone to tsunami.

When paying close attention to scenario 1 simulation, most residents tended to take evacuation route to Kuta Village Hall. This could be assumed that they thought the Kuta Village Hall has a considerable distance from the beach. However, this could be harmful because it would lead to accumulation on the evacuation route because the residents more dominantly chose the Kuta Village Hall compared to the Mandalika Art Market. Therefore, it would lead to increasing disaster risk.

On Figure 14 (a) which is the location of Kuta Village Hall, it could be seen that almost all of the residents already went into the safe location, but there was still a lot of accumulation on the narrow streets. On Figure 14 (b) which is the location of Kuta Village Mandalika Art Market, it could be seen that the accumulation also occurred on the narrow streets, this then would disrupt the evacuation process, which could lead into increasing disaster risk.

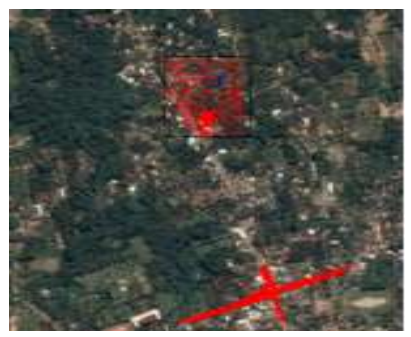

(a) Kuta Village Hall 
In scenario 2 simulation, it used assumption that all of the residents already got good socialization and are ready to conduct evacuation at the beginning of tsunami warning. From the simulation result, it could be seen that the access to evacuation location already uses asphalt material, yet still relatively narrow to the direction of Kuta Village Hall and Kuta Village Mandalika Art Market. In scenario 2 simulation, with time period of $\leq 20$ minutes, residents that could reach both evacuation locations were of $93.27 \%$, as shown in Figure 15 (a) for the Kuta Village evacuation location and Figure 15 (b) for Kuta Village Mandalika Art Market.

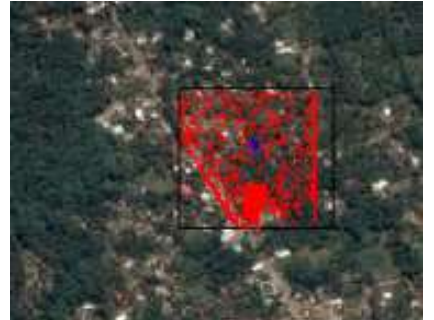

(a) Kuta Village Hall

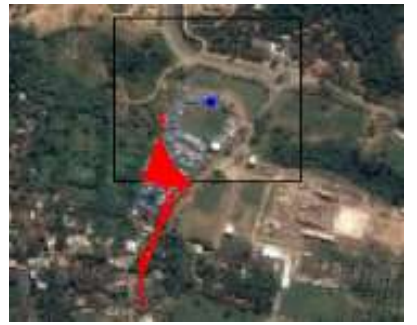

(b) Mandalika Art Market
Figure 15. Details on Scenario 2 Simulation Process

Table 4 shows the comparison of total survivors and Table 5 shows the comparison of the percentage of the survivors from simulation 1 and simulation 2 on evacuation time $\leq 20$ minutes. The total survivors of simulation 2 were of 7,663 people or $93.27 \%$, this is more than survivors in simulation 1, which was 5.227 people or $63.62 \%$.

Table 4. Comparison of total survivors on simulation1and 2

\begin{tabular}{llll}
\hline \multirow{2}{*}{$\begin{array}{l}\text { Minute } \\
\text { of }\end{array}$} & \multirow{2}{*}{$\begin{array}{l}\text { Total population } \\
\text { (people) }\end{array}$} & \multicolumn{2}{l}{ Total survivors (people) } \\
\cline { 3 - 4 } & & Simulation & Simulation \\
0 & 8,216 & 0 & 2 \\
\hline 5 & 8,216 & 361 & 0 \\
10 & 8,216 & 6,150 & 2,452 \\
15 & 8,216 & 4,326 & 5,471 \\
20 & 8,216 & 5,227 & 7,617 \\
\hline
\end{tabular}

Table 5. Comparison of percentage of survivors simulation 1 and 2

\begin{tabular}{llll}
\hline \multirow{2}{*}{$\begin{array}{l}\text { Minute } \\
\text { of }\end{array}$} & $\begin{array}{l}\text { Total population } \\
\text { (people) }\end{array}$ & $\begin{array}{l}\text { Percentage of survivors } \\
(\%)\end{array}$ \\
\cline { 3 - 4 } & & $\begin{array}{l}\text { Simulation } \\
1\end{array}$ & $\begin{array}{l}\text { Simulation } \\
2\end{array}$ \\
\hline 0 & 8,216 & 0.00 & 0.00 \\
5 & 8,216 & 4.39 & 29.84 \\
10 & 8,216 & 25.15 & 66.59 \\
15 & 8,216 & 47.35 & 84.19 \\
20 & 8,216 & 63.62 & 93.27 \\
\hline
\end{tabular}

Figure 16 shows the graph on comparison of total population and Figure 17 shows the graph on percentage of survivors on simulation 1 and 2 on evacuation time $\leq 20$ minute. Total survivors on simulation 2 were increased of 2,436 people or $29.69 \%$. This is because on simulation 2 , the residents already got good socialization and were ready to do evacuation at time of earthquake event.

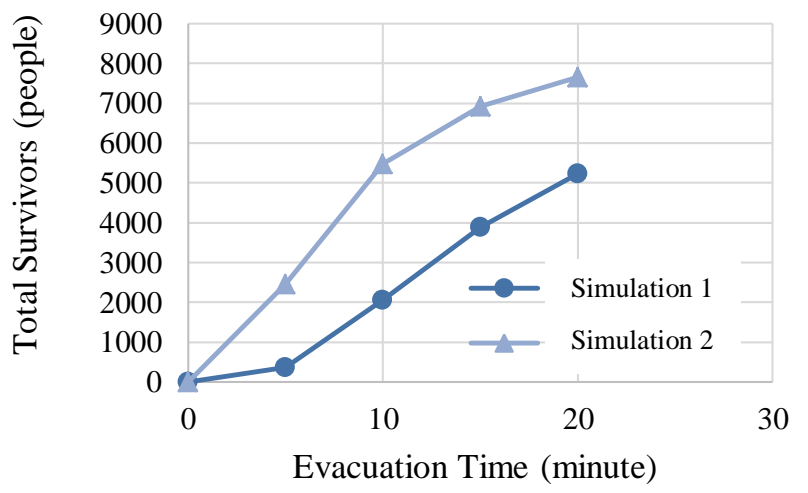

Figure 16. Total survivors on scenario simulation 1 and 2

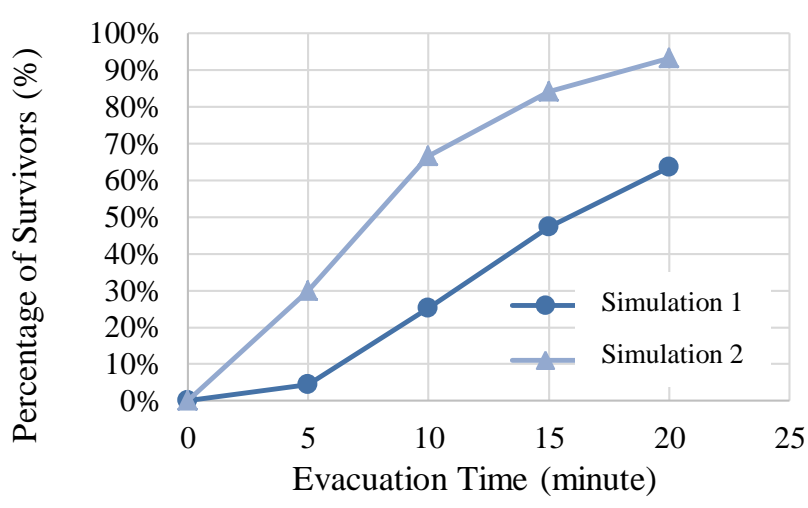

Figure 17. Percentage of survivors on scenario simulation 1 and 2

The increase in survivor number was also affected by temporary shelter location. The Art Market temporary shelter condition that is located on height of 10 masl and distance of \pm 650 meters from the shore could accelerate people to arrive at temporary shelter. The utilization of Art Market temporary shelter area that is previously used for souvenir commerce for tourists made it easier for people to find temporary shelter location. Based on the conducted tsunami simulations result, the Mandalika Art Market temporary shelter location was included on inundation area, therefore mitigation effort is needed by vertical evacuation building. Vertical evacuation building in Art Market temporary shelter must be suitable with earthquakeresistant building standard because tsunami event is usually preceded with earthquake. The building must 
have at least two floors. The building capacity must be able to accommodate people in large number and able to be accessed 24 hours. In this study, researchers did not discuss the design of vertical evacuation building. The researchers just gave input on where the effective point of building location.

Construction of vertical evacuation building indeed cost a lot of budgets. Before the construction plan for vertical evacuation building was made by the government of Central Lombok Regency, the researchers suggested for visitors to be included to evacuate to nearest temporary shelter. Art Market temporary shelter and Kuta Village Hall are very suitable to be used for temporary shelter location.

The existence of signs for evacuation direction is very important to facilitate the evacuation process. The evacuation signs in Kuta Beach need to be added because the number of existing signs is very lacking and most of it has already been pulled out. The more evacuation signs, the easier people to evacuate to existing temporary shelter. The installed signs must be adjusted to nearest temporary shelter location and the installation must be in the location that is easy to be seen.

The conducted simulations were one of the possibilities of tsunami evacuation in Kuta Beach. Various kind of simulation scenarios with various assumptions is needed for further research, in order to obtain the optimal evacuation location.

The height of inundation should also be considered in the tsunami evacuation simulation. Residents are said to be safe if the inundation boundary is passed, even though the evacuation area has not been reached. Inundation with height of $20-50 \mathrm{~cm}$ could still be considered safe, but if it is submerged until $100 \mathrm{~cm}$, it would be dangerous for people due to falling possibility and pushes from materials. Inundation height of $\leq 60 \mathrm{~cm}$ would be very dangerous for children of $\leq 10$ years of age. Adults could still be in dangerous area if they are in altitude of $\geq 100 \mathrm{~cm}$. These criteria were not known and could not be calculated in the Evacuate program.

\section{CONCLUSIONS AND SUGGESTIONS}

\subsection{Conclusions}

According to the results, some conclusions can be drawn as follows:

a) From simulation result with earthquake magnitude variations of $\mathrm{Mw}=7.7 ; \mathrm{Mw}=8.1$; and $\mathrm{Mw}=8.3$; the tsunami arrival time shown was 21 minutes to 38 minutes. Maximum tsunami wave was 1.01 meters to 8.71 meters. Farthest tsunami inundation area was until 860 meters.

b) Highest run-up elevation, longest inundation duration, and fastest time of tsunami wave to reach the land were found in scenario 3 $(\mathrm{Mw}=8.3)$.

c) From the questionnaire interview, evacuation delay time of each respondent were $28 \%$ of 1 minute, $31 \%$ of 5 minutes, $6 \%$ of 10 minutes, $12 \%$ of 15 minutes, and $23 \%$ of 20 minutes.

d) Number of total survivors on scenario 1 simulation was of 5,227 people with percentage of $63.62 \%$, while on scenario 2, the total survivors increased to 7,662 people with percentage of $93.27 \%$.

e) Kuta Village Hall and Mandalika Art Market could be used for safe location from tsunami disaster because of its adequate space aspect.

\subsection{Suggestion}

The followings are some suggestions which may be fruitful for further research:

a) Tsunami early warning system could be utilized for tsunami wave event in magnitude 8.3 scenario.

b) Evacuation to be conducted before the $21^{\text {st }}$ minute on tsunami event with magnitude scenario of 8.3 .

c) Safe location to be set above the 8.71 meters elevation for tsunami event with magnitude scenario of 8.3.

d) The vertical evacuation building is expected to be built according to building criteria and the condition of the people.

\section{REFERENCES}

Federal Emergency Management Agency, 2008. Guidelines for Design of Structures for Vertical Evacuation from Tsunamis. California: FEMA.

Benazir, 2016. Pengembangan Metode Simulasi Runup Tsunami dan Aplikasinya pada Beberapa Kasus Tsunami di Indonesia. [Development of Tsunami Runup Simulation Methods and Application to Several Tsunami Cases in Indonesia]. Yogyakarta: Universitas Gadjah Mada.

BPS Kabupaten Lombok Tengah, 2016. Lombok Tengah dalam Angka. [Central Lombok in Number]. Lombok Tengah: BPS Kabupaten Lombok Tengah.

Kongko, W., 2011. South Java Tsunami Model Using Highly Resolved Data and Probable Tsunamigenic Sources. Germany: Leibniz Universitaet Hannover. 
Nakamura, S., 1979. Note on the Indonesian Earthquake and Tsunami of 19 August 1977. Japanese Journal of Southeast Asian Studies, pp. 157-162.

Scripps Institution of Oceanography, 2017. Extract XYS Grid - Topography of Gravity. [Online] Available at: http://topex.ucsd.edu/cgibin/get_data.cgi

Sudiartha, G. \& Santoso, K., 2011. Rekomendasi Pengembangan Sistem Peringatan Dini Tsunami di
Lombok Nusa Tenggara Barat. Mataram: BPBDNTB.

Triatmadja, R., 2015. Numerical Simulation of An Evacuation Front Tsunami at Parangtritis Beach in Indonesia. Journal of Tsunami Society International, pp. 50-66.

USGS, 2017. Earth Explorer. [Online] Available at: https://earthexplorer.usgs.gov/ 